fever: clinical virology in hospitalized patients. $J$ Infect Dis 1987;155: 456-64.

6 Fraser DW, Campbell CC, Monath TP, Golf PA, Gregg MB. Lassa fever in the eastern province of Sierra Leone, 1970-1972. I. Epidemiologic studies. Am J Trop Med Hyg 1974;23:1131-9.

7 Keane E, Gilles HM. Lassa fever in Panguma Hospital, Sierra Leone, 1973-6. BrMed J 1977; ;:1399-402.

8 McCormick JB, King IJ, Webb PA, et al. Lassa fever: a case-control study of the clinical diagnosis and course. I Infect Dis 1987;155:445-55.

9 McCormick JB, King IJ, Webb PA, et al. Lassa fever: effective therapy with ribavirin. N Engl J Med 1986;314:20-6.
10 Monath TP, Mertens PE, Patten R. A hospital epidemic of Lassa fever in Zorzor, Liberia, March-April, 1972. Am J Trop Med Hyg 1973;22:773-9.

11 Smart YC, Cox J, Roberts TK, Brinsmead MW, Burton RC. Differential effect of cigarette smoking on recirculating T-lymphocyte subsets in pregnant women. I Immunol 1986;137:1-3.

12 Lederman MM. Cell-mediated immunity and pregnancy. Chest 1984;86:6-9S. 3 Helmick CG, Scribner CL, Webb PA, Krebs JW. No evidence for increased risk of Lassa fever infection in hospital staff. Lancet 1986;ii:1202-4.

(Accepted II May 1988)

\title{
High prevalence of diabetes in an urban population in south India
}

\author{
A Ramachandran, M V Jali, V Mohan, C Snehalatha, M Viswanathan
}

\begin{abstract}
An urban population in a township in south India was screened for diabetes with an oral glucose tolerance test, every fifth person aged 20 and over registered at the local iron ore company's hospital being screened. Of 678 people (346 men and 332 women) who were tested, 34 ( $5 \%$; 20 men and 14 women) had diabetes and 14 (2\%; 8 men and 7 women) had impaired glucose tolerance. Thirteen subjects were already known to be diabetic. Diabetes was present in $21 \%(37 / 179)$ of people aged over 40 . The peak prevalence $(41 \% ; 7 / 17)$ was in the group aged 55-64. A family history of diabetes was present in 16 of the 34 subjects with diabetes and nine of the 15 with impaired glucose tolerance. Diabetes was signifcantly related to obesity in women but not in men $(57 \%(8 / 14) v 5 \%(1 / 20))$. The plasma glucose concentration two hours after glucose loading was correlated to body mass index, age, and income in both sexes. The prevalence of diabetes was significantly higher in subjects whose income was above the mean.
\end{abstract}

When the overall prevalence of diabetes was adjusted to the age distribution of the Indians living in Southall, London, and in Fiji it increased to $10 \%$ and $9 \%$, respectively. The prevalence of diabetes is high among urban Indians and is comparable with the high prevalence seen in migrant Indian populations.

\section{Introduction}

The prevalence of diabetes varies in different populations. A high prevalence has been reported in migrant Indians in South Africa, Fiji, Trinidad, Singapore, and Southall (London). ${ }^{1.5}$ The prevalence in Indians in India was believed to be low, ${ }^{6}$ but a recent survey in Darya Ganj (New Delhi) showed that the prevalence of known diabetes was not different from that seen in Indians in Southall. ${ }^{57}$ The surveys were based on questionnaires, not on results of tests; hence they probably underestimated the actual prevalence of diabetes. We used glucose tolerance tests to determine the prevalence of diabetes in a population in south India.

$\begin{array}{ll}\text { department of } & \text { the previL, head, } \\ \text { India. }\end{array}$

biochemistry

$\mathrm{M}$ Viswanathan, $\mathrm{MD}$, director

\section{Kudremukh Iron Ore Company Hospital, Kudremukh, India MV Jali, MD, assistant medical officer}

Correspondence to: $\operatorname{Dr} A$ Ramachandran, Diabetes Research Centre, Royapuram, Madras 600013 , India.

\section{Patients and methods}

The survey population came from a township in Kudremukh, Chicmagalur district Karnataka, south India. The population of the township includes several hundred executives and skilled and unskilled workers employed by the Kudremukh Iron Ore Company. They and their families are given free medical care in the hospital attached to the company. The staple food of the people is rice. We selected this area for study because population based data could be obtained from the hospital register and the population was relatively stable.

Of the 4619 people registered at the hospital, 3314 were aged 20 and above; they were defined as the target population. A letter requesting participation in the study was written to every fifth person (selected from the registration numbers on the computer list). The overall response was good because of the well organised health scheme for the community and the close rapport between physicians and the families. The defaulters (less than $1 \%$ after three requests) were replaced by the person having the next number on the computer list. The sample was representative of the overall population.

Subjects came to the hospital at 8 am after an overnight fast, and a fasting sample of venous blood was taken for estimation of plasma glucose and serum cholesterol concentrations. Then $75 \mathrm{~g}$ glucose was given orally in $200 \mathrm{ml}$ water, and blood samples were collected after one and two hours. (This glucose tolerance test was not performed if the subject was known to be diabetic and receiving treatment.) During the time between sampling, height, weight, the family history of diabetes, and family income were ascertained.

Glucose tolerance was classified according to the criteria in a report of the World Health Organisation's study group. ${ }^{8}$ Diabetes was diagnosed if the concentration of glucose in fasting venous plasma was $\geqslant 7.8 \mathrm{mmol} / \mathrm{l}$ or if the concentration of glucose in venous plasma two hours after the glucose loading was $\geqslant 11.1 \mathrm{mmol} / \mathrm{l}$, or both. Impaired glucose tolerance was diagnosed if the plasma glucose concentration two hours after the glucose loading was $7 \cdot 8$ to $11 \cdot 1 \mathrm{mmol} / \mathrm{l}$.

The body mass index $\left(\mathrm{kg} / \mathrm{m}^{2}\right)$ of each subject was calculated. Obesity was defined as a body mass index $>25 \mathrm{~kg} / \mathrm{m}^{2}$ in women and $>27 \mathrm{~kg} / \mathrm{m}^{2}$ in men. Family histories of diabetes were ascertained by questionnaire. They were taken as positive only if there was a history of drug treatment for diabetes. Family income was grouped as $<500$, 501-1000, 1001-1500, 1501-2500, and $>2500$ rupees a month.

The plasma glucose concentration was estimated by the orthotoluidine method' and serum cholesterol concentration by the method of Wybenga et al. ${ }^{10}$ Samples were sent to the Diabetes Research Centre, Madras, three times during the study for counterchecking of the plasma glucose and cholesterol concentrations; the coefficient of variation between the two laboratories was 4-8\%.

The $\chi^{2}$ test and Fisher's test were used for univariate analysis. The prevalence adjusted for the age distributions seen in other studies was calculated by the direct standardisation method. " Analyses of variance were used to determine the effect of sex, age, body mass index, and income and the interaction of these factors on the plasma glucose concentrations after 


\begin{tabular}{|c|c|c|c|c|c|c|c|c|c|}
\hline \multirow[b]{2}{*}{ Age (years) } & \multicolumn{4}{|c|}{ Men } & \multicolumn{4}{|c|}{ Women } & \multirow[b]{2}{*}{$\begin{array}{l}\text { Total with } \\
\text { abnormal } \\
\text { glucose } \\
\text { tolerance }(\%)\end{array}$} \\
\hline & No tested & $\begin{array}{c}\text { No }(\%) \text { with } \\
\text { diabetes found } \\
\text { on testing }\end{array}$ & $\begin{array}{l}\text { No known to } \\
\text { have diabetes }\end{array}$ & $\begin{array}{l}\text { No (\%) with } \\
\text { impaired } \\
\text { glucose } \\
\text { tolerance }\end{array}$ & No tested & $\begin{array}{c}\text { No }(\%) \text { with } \\
\text { diabetes on } \\
\text { testing }\end{array}$ & $\begin{array}{l}\text { No known to } \\
\text { have diabetes }\end{array}$ & $\begin{array}{l}\text { No (\%) with } \\
\text { impaired } \\
\text { glucose } \\
\text { tolerance }\end{array}$ & \\
\hline $20-24$ & 46 & & & & 86 & & & $1(1)$ & $1 / 132(1)$ \\
\hline $25-34$ & 134 & $3(2)$ & 1 & $3(2)$ & 150 & $3(2)$ & 2 & $2(1)$ & $11 / 284(4)$ \\
\hline $35-44$ & 118 & $7(6)$ & 3 & $3(3)$ & 67 & $4(6)$ & 2 & $2(3)$ & $16 / 185(9)$ \\
\hline $45-54$ & 35 & $7(20)$ & 2 & $1(3)$ & 18 & $3(17)$ & 1 & $1(6)$ & $12 / 53(23)$ \\
\hline $55-64$ & 9 & $2(22)$ & 1 & $1(11)$ & 8 & $3(38)$ & 1 & l(13) & $7 / 17(41)$ \\
\hline$\geqslant 65$ & 4 & $1(25)$ & & & 3 & $1(33)$ & & & $2 / 7(29)$ \\
\hline Total & 346 & $20(6)$ & 7 & $8(2 \cdot 3)$ & 332 & $14(4)$ & 6 & $7(2)$ & $49 / 678(7)$ \\
\hline
\end{tabular}

two hours and the serum cholesterol concentrations. Multiple regression analysis was done separately in men and women to assess the effects of age, body mass index, and income on the glucose concentrations after two hours and cholesterol concentrations. The data were stored and processed by a BPL Sanyo MBC 885 computer. The study was carried out during 1985 and took six months to complete.

\section{Results}

Of the 3314 subjects registered at the hospital who were were aged 20 and above, 1676 were men and 1638 were women; 678 ( 346 men and 332 women) were tested for diabetes (table I). Diabetes was present in 34 $(5 \% ; 20$ men and 14 women) and impaired glucose tolerance in 15 ( $2 \%$, eight men and seven women). Thus a total of $49(7 \%)$ had abnormal glucose tolerance. Thirteen of those with diabetes were receiving treatment. All diabetic patients had non-insulin dependent diabetes. The crude prevalence of diabetes was higher in men $(6 \%)$ than women $(4 \%)$. Analysis of variance showed that the prevalence in either sex did not vary significantly. The women, however, had a younger age distribution, and the prevalence increased to $7 \%$ in the women when it was adjusted to the age distribution of the men. Diabetes occurred in $2 \%$ $(10 / 499)$ of the population aged under 40 and in $21 \%$

TABLE II-Relation of plasma glucose and serum cholesterol concentrations two hours after glucose loading to several variables (analysis of variance)

\begin{tabular}{|c|c|c|c|c|c|c|}
\hline & \multicolumn{3}{|c|}{ Glucose } & \multicolumn{3}{|c|}{ Cholesterol } \\
\hline & $\mathrm{df}$ & F ratio & $\mathrm{p}$ Value & $\mathrm{df}$ & F ratio & $\mathrm{p}$ Value \\
\hline Sex & 1 & $2 \cdot 23$ & NS & 1 & $2 \cdot 23$ & NS \\
\hline Age & 5 & 3.48 & $<0.01$ & 5 & 1.76 & NS \\
\hline Body mass index & 2 & $6 \cdot 27$ & $<0.05$ & 2 & $4 \cdot 73$ & $<0.01$ \\
\hline Income & 2 & 3.53 & $<0.05$ & 2 & $2 \cdot 37$ & NS \\
\hline Glucose at 2 hours & & & & 2 & $5 \cdot 23$ & $<0.01$ \\
\hline Sex $\times$ age & 5 & 1.98 & NS & 5 & 1.76 & NS \\
\hline Sex $\times$ body mass index & 2 & $4 \cdot 23$ & $<0.05$ & 2 & $2 \cdot 13$ & NS \\
\hline Sex $\times$ income & 2 & $2 \cdot 32$ & NS & 2 & 1.96 & NS \\
\hline Sex $\times$ glucose at 2 hours & & & & 2 & $2 \cdot 43$ & NS \\
\hline Age $\times$ body mass index & 10 & $2 \cdot 46$ & $<0.01$ & 10 & 1.64 & NS \\
\hline Age $\times$ income & 10 & $2 \cdot 84$ & $<0.01$ & 10 & 1.57 & NS \\
\hline Age $\times$ glucose at 2 hours & & & & 10 & 1.46 & NS \\
\hline Body mass index $\times$ income & 4 & $3 \cdot 16$ & $<0.05$ & 4 & 1.98 & NS \\
\hline $\begin{array}{l}\text { Body mass index } \times \text { glucose at } \\
2 \text { hours }\end{array}$ & & & & 4 & 2.02 & NS \\
\hline Income $\times$ glucose at 2 hours & & & & 4 & $2 \cdot 14$ & NS \\
\hline
\end{tabular}

(37/179) aged 40 and above. The peak prevalence was in the group aged 55-64. Analysis of variance showed that the glucose concentration at two hours was significantly related to age ( $\mathrm{p}<0.01$; table II); multiple regression analysis showed that this was true in both men and women $(\mathrm{p}<0.01$; table III).

As our population was younger than most migrant Indian groups we adjusted the prevalence to the age distribution of the populations in two other studiesnamely, Southall in England (by the 1980 census $^{5}$ ) and Indians who had migrated to urban areas of Fiii. When adjusted to the age distribution in Southall the prevalence was $10 \%$ (compared with $2 \cdot 2 \%$ in that study), and when adjusted to the age distribution in Fiji it was $9 \%$ (compared with $13 \%$ ).

A family history of diabetes was present in $16(47 \%)$ of the diabetics $\left(\chi^{2}=24 \cdot 7, p<0.001\right)$ and nine $(60 \%)$ of those with impaired glucose tolerance $(p<0.001$, Fisher's test) compared with $87(14 \%)$ of the subjects who did not have diabetes. Thus $51 \%$ of those with abnormal glucose tolerance had a family history of diabetes.

Obesity was more common in women $(89 / 332(27 \%)$ than men $(18 / 344)(5 \%))\left(\chi^{2}=56 \cdot 45, \mathrm{p}<0 \cdot 001\right)$. Nine $(26 \%)$ of the 34 diabetics were obese. Of the 18 obese men, one $(6 \%)$ had diabetes and one impaired glucose tolerance, whereas of the 89 obese women, eight $(9 \%)$ had diabetes and six $(7 \%)$ impaired glucose tolerance. Diabetes was significantly related to obesity in the women but not the men $(p<0 \cdot 001$, Fisher's test); eight of the 14 diabetic women compared with only one of the 20 diabetic men were obese. Multiple regression analysis showed that body mass index was significantly correlated with the glucose concentration at two hours in both men and women (table III), and analysis of variance that the glucose concentration at two hours was significantly related to body mass index, sex and body mass index, age and body mass index, and body mass index and income (table II).

The mean income of the subjects tested was 1550 rupees per month. Diabetes and impaired glucose tolerance were more prevalent in the 208 subjects with a monthly income over 1500 rupees; $16(8 \%)$ were diabetic compared with $18(4 \%)$ of the 470 subjects with a monthly income below 1500 rupees, and eight (4\%) had impaired glucose tolerance compared with $7(15 \%)$ in the lower income group. The glucose

TABLE III-Multiple linear regression analysis relating glucose concentrations at two hours and cholesterol concentration to age, body mass index, and income

\begin{tabular}{|c|c|c|c|c|c|c|c|c|c|c|c|c|}
\hline & \multicolumn{6}{|c|}{ Glucose at 2 hours } & \multicolumn{6}{|c|}{ Serum cholesterol } \\
\hline & \multicolumn{3}{|c|}{ Men } & \multicolumn{3}{|c|}{ Women } & \multicolumn{3}{|c|}{ Men } & \multicolumn{3}{|c|}{ Women } \\
\hline & $\begin{array}{l}\text { Regression } \\
\text { coefficient } \\
\text { (B) }\end{array}$ & $t$ Value & $\mathrm{p}$ Value & $\begin{array}{l}\text { Regression } \\
\text { coefficient } \\
\text { (B) }\end{array}$ & $t$ Value & $\mathrm{p}$ Value & $\begin{array}{l}\text { Regression } \\
\text { coefficient } \\
\text { (B) }\end{array}$ & $t$ Value & $\mathrm{p}$ Value & $\begin{array}{l}\text { Regression } \\
\text { coefficient } \\
\text { (B) }\end{array}$ & $t$ Value & $\mathrm{p}$ Value \\
\hline $\begin{array}{l}\text { Age } \\
\text { Body mass index } \\
\text { Income } \\
\text { Glucose at } 2 \text { hours } \\
\text { Multiple correlation }\end{array}$ & \multicolumn{3}{|c|}{$\begin{array}{l}\mathrm{R}^{2}=0.2225 \\
(\mathrm{p}<0.01) \\
\mathrm{B}_{0}=-46.57\end{array}$} & \multicolumn{3}{|c|}{$\begin{array}{l}\mathrm{R}^{2}=0.3991 \\
(\mathrm{p}<0 \cdot 01) \\
\mathrm{B}_{0}=36 \cdot 11\end{array}$} & $\begin{array}{l}0 \cdot 242 \\
2 \cdot 45 \\
0 \cdot 003 \\
2 \cdot 14\end{array}$ & $\begin{array}{l}0 \cdot 184 \\
2 \cdot 71 \\
0 \cdot 183 \\
3 \cdot 91 \\
\mathrm{R}^{2}=0 \cdot 2 \\
(\mathrm{p}<0 \cdot 0 \\
\mathrm{B}_{\mathrm{a}}=-1\end{array}$ & $\begin{array}{c}\quad N S \\
<0.01 \\
N S \\
<0.001 \\
22\end{array}$ & \multicolumn{3}{|c|}{$\begin{array}{l}2 \cdot 49 \\
\mathrm{R}^{2}=0.2579 \\
(\mathrm{p}<0.01) \\
\mathrm{B}_{4}=101 \cdot 274\end{array}$} \\
\hline
\end{tabular}




\begin{tabular}{|c|c|c|c|c|c|c|}
\hline \multirow[b]{2}{*}{ Age (years) } & \multicolumn{2}{|c|}{ Normal glucose tolerance } & \multicolumn{2}{|c|}{ Diabetic } & \multicolumn{2}{|c|}{ Impaired glucose tolerance } \\
\hline & $\begin{array}{l}\text { Mean (SD) } \\
\text { cholesterol }\end{array}$ & $\begin{array}{c}\text { No of } \\
\text { subjects }\end{array}$ & $\begin{array}{l}\text { Mean (SI) } \\
\text { cholesterol }\end{array}$ & $\begin{array}{c}\text { No of } \\
\text { subjects }\end{array}$ & $\begin{array}{l}\text { Mean (SD) } \\
\text { cholesterol }\end{array}$ & $\begin{array}{c}\text { No of } \\
\text { subjects }\end{array}$ \\
\hline $20-24$ & $3.7(0.7)$ & 130 & & & 4.5 & 1 \\
\hline $25-34$ & $4 \cdot 0(0.6)$ & 267 & $4.8(1.5)$ & 6 & $3.9(0.5)$ & 5 \\
\hline $35-44$ & 4.40 .8 & 168 & $4.5(0.7)$ & 11 & $4.9(0.4)$ & 5 \\
\hline $45-54$ & $4.6(1.0)$ & 43 & $4.9(1 \cdot 7=$ & 10 & $5 \cdot 0(0.9)$ & 2 \\
\hline $55-64$ & $4 \cdot 7(10)$ & 15 & $5 \cdot 0(1 \cdot 1)$ & 5 & $5 \cdot 41.5$ & 2 \\
\hline$\geqslant 65$ & $4 \cdot 1(0.3)$ & 6 & $5 \cdot 2(1 \cdot 1)$ & 2 & & \\
\hline
\end{tabular}

The Darya Ganj survey was of an affluent population (mean monthly income 2500 rupees, whereas the mean monthly income in our population was 1500 rupees). Only $46(7 \%)$ people in our study had an income over 2500 rupees per month; the prevalence of diabetes among them was $17 \%$. The effect of income was confounded by age and body mass index.

The high prevalence of diabetes in urban Indians found in our study and in the survey from Darya Ganj is notable in the light of the reports of a high prevalence among migrant Indian populations living outside India. ${ }^{1.5}$ The Southall survey found no difference in adiposity between Indians and Europeans and no factor that might explain the high prevalence. When the prevalence in our study was adjusted to the age distributions of the Indians in the Southall study and the study in urban Fiji it increased further (to $10 \%$ and $9 \%$ respectively). Comparison with the population in Fiji is more appropriate as the subjects were tested for diabetes; the prevalence in Fijian Indians was 13.2\%.

Diabetes was more prevalent in men than women, the ratio being $1 \cdot 3: 1$ for diabetes and $1 \cdot 1: 1$ for impaired glucose tolerance. Analysis of variance, however, did not show a significant difference. Previous studies have reported a higher prevalence in Indian men. ${ }^{61+15}$ When adjustment was made for the younger age of the women in our study the prevalence of diabetes was higher among women. Only one previous report, from South Africa, has shown a higher prevalence of diabetes among women than men. ${ }^{\text {to }}$

Obesity is an important risk factor in diabetes, and in the Western world most patients with diabetes are obese. ${ }^{17}$ Obesity is not common in Indian diabetics. ${ }^{15}$ In our study only a quarter of the diabetics were obese, but obesity was more common in women. Univariate analysis showed that diabetes was significantly more common in obese women but not in obese men.

All the patients in our study had non-insulin dependent diabetes. The prevalence of insulin dependent diabetes is believed to be low in Indians. ${ }^{1+}$

Impaired glucose tolerance was found in $2 \%$ of the population we tested. In a previous follow up study one third of Indians with impaired glucose tolerance developed diabetes (mean follow up period four years). ${ }^{18}$ Half of our subjects with abnormal glucose tolerance had a family history of diabetes. We have previously reported a high degree of familial aggregation among Indian diabetics and a high prevalence of diabetes among children who had one or two diabetic parents. ${ }^{19}: 1$ Hoskins et al also found that a family history of diabetes was a risk factor for diabetes in Melanesians and Indians living in Fiji. ${ }^{12}$

In conclusion, we found that the prevalence of diabetes is high among Indians living in an urban area of India and is comparable with the prevalence in migrant Indian populations living outside India.

We thank Dr Paul Zimmet and Dr Gary Douse of the Royal Southern Memorial Hospital, Caulfield, Australia, for their guidance and critical review of the manuscript; Dr John Jarrett and Dr Harry Keen of Guy's Hospital, London, for their advice in processing and presenting the data; $\mathrm{Dr}$ Manjula Dutta and Dr V Kumaraswamy of the Institute of Chest Diseases, Madras, for their help in statistical analysis; and Mr S T Arasu of the computer department of the Diabetes Research Centre and the staff of the computer centre of the Kudremukh Iron Ore Company for their valuable help. in Southall, London, showed that its prevalence was $2 \cdot 2 \%$ in migrant Indians and $1 \cdot 2 \%$ in Europeans. ${ }^{5}$ Both the Darya Ganj and the Southall studies surveyed large populations but did not actually test for diabetes. Studies based on known diabetics underestimate the true prevalence of the disease. Furthermore, the respondents in these surveys were of north Indian origin, being mainly Punjabis. Few data exist on the prevalence of diabetes among populations from south India.

1 Marine N, Vinik AI, Edelstein I, et al. Diabetes, hyperglycemia and glycosuria among Indians, Malays and Africans (Bantu) in Cape Town, South Africa. Diabetes 1969;18:840-57.

2 Zimmet P, Tavlor R, Ram P, et al. The prevalence of diabetes and impaired glucose tolerance in the biracial (Melanesian and Indian) population of Fiji: glucose tolerance in the biracial (Melanesian and Indian) popul
rural-urban comparison. Am f Epidemiol 1983;118:673-88.

3 Poon-King T, Henry MV, Rampersad F. Prevalence and natural history of diabetes in Trinidad. Lancet 1968;i:155-60.

4 Cheah JS, Lui KF, Yeo PPB, Tam BY, Tanayk YT. Diabetes mellitus in Singapore: results of a country wide population survey. In: Ahuja MMS, ed. 
Epidemiology of diaheles in developing countries. New Delhi: Interprint, 1979:93-102

5 Mather HM, Keen $\mathrm{H}$. The Southall diabetes survev: prevalence of diabetes in Asians and Europeans. Br Med 7 1985;291:1081-4.

6 Ahuja MMS. Epidemiological studies on diabetes mellitus in India. In: Ahuja MMS, ed. Epidemiology of diabeles in developing countries. New Delhi: Interprint, 1979;29-38.

7 Verma NPS, Mehta SP, Madhu S, Mather HM, Keen H. Prevalence of known diabetes in an urban Indian environment: the Darya Ganj diabetes survey. diabetes in an urban Indian
Br Med $\mathcal{Y} 1986: 293: 423-4$

8 World Health Organisation. Diabetes mellitus. WHO Tech Rep Ser 1985; No 727

9 Hyvarinen A, Nikkila EA. Specific determination of blood glucose with orthotoluidine. Clin Chim Actu 1962;7:140-3.

10 Wybenga DR, Pileggi VJ, Dirstine PH, el al. Direct manual determination of serum total cholesterol with a single stable reagent. Clin Chem 1970;16 980-4.

11 Lavori PW, Louis TA, Bailar JC, Polansky M. Design for experimentsparallel comparisons of treatment. In: Bailar JC, Mosteller F, eds. Medicul uses of stutistics. Waltham, MA: Massachusetts Medical Society, 1986:41-66.

12 Hoskins PL, Handelsman DJ, Hannelly T, Silink M, Yue DK, Turtle JR. Diabetes in the Melanesian and Indian peoples of Fiji: a study of risk factors. Diabeles Res Clin Pract 1987;3:269-76. 13 Thai AC, Yeo PFB, Lun KC, et al. Changing prevalence of diabetes mellitus in

14 Ramachandran A, Gallaghar F, Mohan V, et al. Comparative study of the elinical pattern of diabetes from two referral centres for diabetes in the United States of America and India. Joumal of the Diabetic Association of India 1986;26:83-8

15 Mohan V, Ramachandran A, Viswanathan M. Tropical diabetes. In: Alberti KGMM, Krall LP, eds. The diabetes annual. Vol 2. Amsterdam: Elsevier, 1986:30-8.

16 Omar MAK, Hammond MG, Seedat MA, et al. The prevalence of diabetes mellitus in a large group of South African Indians. S Af Med 7 1985;67. $92+-6$

17 West KM. Diabetes in the tropics: some lessons for western diabetology. In Podulsky S, Viswanathan M, eds. Secondan diabetes: the spectrum of the diabetic syndromes. New York: Raven, 1980:249-55.

18 Ramachandran A, Snehalatha C, Naik RAS, Mohan V, Shobana R, Viswanathan $M$. Significance of impaired glucose tolerance in an Asian Indian population.: a follow-up study. Diabeles Res Clim Pract 1986;2:173-8.

19 Mohan V, Sharp PS, Aber VR, Mather HM, Kohner EM. Family histories of Asian and European non-insulin dependent diabetic patients. Practical Diabeles 1986;3:254-6.

20 Viswanathan M, Mohan V, Snehalatha C, Ramachandran A. High prevalence of type 2 (non-insulin dependent) diabetes among offspring of conjugal type 2 diabetic parents in India. Diabetologia 1986;28:907-10.

21 Kamachandran $A$ Mohan $V$ snchalatha $C$, Viswanathan $M$ l'revalence of non-insulin dependent diabetes mellitus in Asian Indian families with a single diabetic parent. Diabetes Res Clin Pract 1988:4:241-5.

(Accepted 5 Mav 1988)

\title{
Save the prepuce. Painless separation of preputial adhesions in the outpatient clinic
}

\author{
G A MacKinlay
}

\begin{abstract}
In most boys referred for circumcision preputial adhesions are the only problem, but these can predispose to recurrent balanitis. A simple technique using Emla cream (eutectic mixture of lignocaine and prilocaine) has been devised which allows the adhesions to be separated painlessly in the outpatient clinic. The technique was used on 39 boys aged 2 to 12 years referred for circumcision, none of whom had a retractable foreskin. The cream was applied under an occlusive dressing and left for $\mathbf{6 0}$ minutes before the adhesions were separated with a probe and a gauze swab. The procedure was completely pain free in 32 boys. One boy had to undergo a repeated procedure because he failed to follow the advice regularly to retract his foreskin in the three weeks after the procedure. Only one boy had to undergo circumcision later because of fibrous phimosis.

In many boys referred for circumcision separation of preputial adhesions is all that is needed, and the use of this local anaesthetic technique avoids the need for general anaesthesia.
\end{abstract}

\section{Introduction}

Non-retractability of the foreskin has has been a common pretext for circumcision. A non-retractable prepuce is not, however, synonymous with phimosis and it should not be used as an excuse for "lopping off an innocent and useful appendage." It has been claimed that the difference between intercourse with a circumcised and an uncircumcised penis is "the difference between slipping the foot into a sock that has been rolled up and one that is held open at the top." Bokai, in 1860, was the first to draw attention to the physiological adherence of the foreskin.

In 1927 Hamilton and Middleton reported from this hospital an investigation into phimosis and dysuria in infancy and concluded that circumcision was carried out too frequently. ${ }^{+}$In many cases separation of adhesions is all that is required. Deibert showed in 1933 that separation of the prepuce in the human penis is due to keratinisation of the subpreputial epithelium, a process not complete at birth but accomplished during early childhood." Apart from religious or tribal reasons there are few indications for circumcision, and its incidence is declining. ${ }^{\top} \mathrm{A}$ fibrous phimosis with scarring undoubtedly necessitates surgery, even in other species. ${ }^{x}$ Balanitis, however, is often quoted as an indication for circumcision, " in my opinion wrongly.

In cases of recurrent balanitis with a non-retractable foreskin separation of adhesions and subsequent preputial hygiene will prevent further attacks without the necessity of circumcision, which may itself predispose to meatitis and possible meatal stenosis." Preputial adhesions have commonly been separated under general anaesthetic, ${ }^{12}$ since separation in the outpatient department is traumatic to the child, even with the use of 5\% lignocaine cream. ${ }^{13}$ The introduction of Emla cream (eutectic mixture of local anaesthetics; Astra Pharmaceuticals), however, led me to investigate its value in allowing painless separation of preputial adhesions.

\section{Patients and methods}

Emla is a formula of lignocaine and prilocaine designed to alleviate the pain of venepuncture. ${ }^{1+}$ Unlike previously available topical preparations, it penetrates intact skin to produce intradermal anaesthesia. It not only reduces the pain of venepuncture in children but also makes the procedure easier. ${ }^{15}$ It has been evaluated in a variety of other indications, in particular split skin grafting and minor skin operations. "1 It must be applied under an occlusive dressing at least 60 minutes before the procedure.

The procedure is as follows. The child first empties his bladder. He then lies on a couch with his parent at the head end for reassurance. The boy is told that some "magic cream" is going to be applied to his penis and warned that it may feel cold. The foreskin is drawn forward over the small open end of the tube of cream and held closely applied with one hand, while the other squeezes a generous quantity (at least half the tube) under the foreskin. The foreskin is then held firmly between thumb and forefinger to prevent any cream from escaping. Any excess is carefully removed with a gauze swab, and a $3 \mathrm{M}$ Tegaderm dressing (supplied with the cream) is applied, the printed paper having

\section{EH9 IL F} senior lecturer in surgical paediatrics 